\title{
PENERAPAN METODE PENGAJARAN BAHASA INGGRIS MIXED ENGLISH PROFICIENCY LEVELS: PERSEPSI GURU
}

\author{
Sri Gustiani ${ }^{1)}$, Tiur Simanjuntak ${ }^{2)}$ (Risnawati ${ }^{3)}$, Munaja Rahma ${ }^{4}$ \\ ${ }^{1}$ Jurusan Bahasa Inggris, Politeknik Negeri Sriwijaya \\ email: srigustiani2011@gmail.com \\ 2 Jurusan Bahasa Inggris, Politeknik Negeri Sriwijaya \\ email: tiur-simanjuntak@yahoo.com \\ ${ }^{3}$ Jurusan Bahasa Inggris, Politeknik Negeri Sriwijaya \\ email: risnawati68@yahoo.com \\ ${ }^{4}$ Jurusan Bahasa Inggris, Politeknik Negeri Sriwijaya \\ email: munaja.rahma@yahoo.com
}

\begin{abstract}
This research is to know teachers' perceptions on methods of teaching English for classes with mixed-English proficiency students: primary, elementary, intermediate, and advance levels. These methods were some differentiated instructions taught in training to teachers of English as a community service activity which conducted to the teachers of English at Lembaga Bahasa (LB) Bagus Palembang. In this training, the participants learned the methods because they did not get the knowledge in their pre-service teacher training. They only had teaching methods for classes with one level of English proficiency. After they completed the training, they were monitored during the methods application in order to find their perceptions on teaching such class. The data were gathered via observations in the class during the monitoring. The observation data were, then, matched to the data from semi-structured interviews to know the participants' perception on the methods in their classes. The research revealed that the methods were proven to increase students' participation in class with notification to high proficiency ones. However, it was not possible to suggest other best practices for dealing with all students in that class because not all practices work in a mixed-English proficiency class.
\end{abstract}

Keywords: mixed-English proficiency, mixed-English ability, teaching methods

\section{PENDAhUluan}

Kemampuan berbahasa Inggris sebagai salah satu bahasa asing di Indonesia dewasa ini sangatlah penting karena dilandasi beberapa kebutuhan. Kebutuhan yang paling utama adalah sebagai alat komunikasi antar bangsa di era globalisasi, dan sebagai alat untuk memahami, menguasai dan mengembangkan ilmu pengetahuan [1], [2]. Dalam era globalisasi ini, Bahasa Inggris berperan sangat penting dalam komunikasi dan interaksi antar bangsa. Berdasarkan hasil riset Crystal [3] yang disari dalam artikel How many people in world speak English?, sebagai alat komunikasi internasional, Bahasa Inggris digunakan di 67 negara dari 195 negara di dunia sebagai bahasa ibu dan 27 negara menggunakannya sebagai bahasa kedua. Riset selanjutnya di tahun 2017 oleh Lyons (2017) menunjukkan bahwa 1.5 milyar dari 7.5 milyar penduduk dunia yang bukan penutur asli menggunakan Bahasa Inggris sebagai alat komunikasi yang berarti $20 \%$ dari populasi seluruh dunia. Sedangkan 360 juta penutur asli menggunakan Bahasa Inggris sebagai bahasa ibu. Hal ini berarti kemampuan berkomunikasi baik lisan dan tulisan menggunakan Bahasa Inggris sebagai bahasa internasional menjadi jembatan dan menempatkan individu dengan keterampilan dan daya saing tinggi dalam berbagai macam lapangan antar negara baik itu bisnis, sosial, politik, maupun budaya.

Seiring dengan penggunaannya secara global, Bahasa Inggris menjadi bahasa utama yang digunakan dalam ilmu pengetahuan. Hampir semua alat teknologi, buku ilmu pengetahuan, karya sastra, hasil riset, dunia hiburan dan situs diseluruh dunia menggunakan dalam Bahasa Inggris [1], [5]. Kemampuan berbahasa Inggris yang handal memungkinkan individu untuk mengakses ilmu pengetahuan tersebut lebih mendalam. Fungsi Bahasa Inggris sebagai akses ilmu pengetahuan yang lebih luas selanjutnya menjadi modal untuk menguasai dan mengembangkan ilmu pengetahuan tersebut. Selain itu, kemampuan berbahasa Inggris 
menjadi salah satu syarat untuk dapat belajar di sekolah dan perguruan tinggi dunia. Oxford, Cambridge, dan Harvard adalah hanya beberapa contoh universitas terkenal yang menempati puncak pendidikan dunia. Bagi pengguna Bahasa Inggris sebagai bahasa asing, disyaratkan nilai kemampuan berbahasa Inggrisnya sebagai bukti mampu mengikuti proses belajar mengajar yang menggunakan Bahasa Inggris sebagai bahasa pengantar.

Dari dua contoh kegunaannya diatas, Bahasa Inggris menjadi bahasa yang paling diminati untuk dipelajari rata-rata penduduk Indonesia, baik pelajar ataupun pekerja. Pemerintah Indonesia telah menjadikan Bahasa Inggris sebagai mata pelajaran atau mata kuliah wajib bagi peserta didik dari tingkat Sekolah Dasar hingga Pendidikan Tinggi dengan harapan pelajar Indonesia mampu bersaing di tingkat global. Namun begitu, jumlah jam pelajaran Bahasa Inggris dan status Bahasa Inggris sebagai bahasa asing di Indonesia tidak lah mencukupi para peserta didik untuk memiliki kemampuan berbahasa Inggris yang diharapkan [1]. Sebagian besar dari mereka belajar bahasa Inggris diluar jam perlajaran sekolah dengan cara mengikuti kelas tambahan di lembaga bahasa/kursus Bahasa Inggris pemerintah atau swasta. Para pekerja pun berusaha untuk meningkatkan profesionalisme dan sumber daya mereka dengan cara memiliki kemampuan berbahasa Inggris sebagai nilai tambah. Beberapa dari mereka mengambil kelas di lembaga bahasa/kursus atau mengadakan kelas Bahasa Inggris khusus di perusahaan mereka sendiri.

Di tahun 2015, di Indonesia tercatat 4.583 lembaga bahasa/kursus swasta penyedia kelas Bahasa Inggris bagi pelajar dan pekerja [6]. Angka ini dipastikan bertambah hingga saat ini, dan menunjukan betapa Bahasa Inggris sangat diminati di Indonesia. Namun kenyataannya, sistim pengajaran yang menekankan pada pengelompokan kemampuan peserta perkelas, misalnya kelas primary, elementary, intermediate, atau advance, yang berlaku di lembaga bahasa/kursus Bahasa Inggris, menimbulkan masalah bagi guru-gurunya.Guru-guru ini mendapat kesulitan bila harus mengajar kelas dengan kemampuan berbahasa Inggris yang beragam. Disatu pihak banyak guru di lembaga bahasa/kursus Bahasa Inggris mengalami kesulitan bila harus mengajar kelas dengan murid yang berkemampuan Bahasa
Inggris beragam (mixed English proficiency level). Sedangkan dipihak lain banyak industri atau dinas/departemen pemerintahan yang meminta kelas khusus untuk pekerja mereka yang memiliki mixed-English proficiency level. Hal ini terjadi karena guru pada lembaga bahasa/kursus Bahasa Inggris mendapatkan pelatihan pedagogi dan mengajarkan materi ajar hanya untuk kelas dengan English proficiency level tertentu dimasa pre-service training mereka.

Keadaan ini mengakibatkan tidak maksimalnya proses belajar mengajar dengan ditandai rendahnya capaian murid kelas-kelas khusus tersebut. Masalah ini juga dihadapi guru-guru Bahasa Inggris di Lembaga Bahasa Bagus (LB Bagus) Palembang (nama disamarkan berdasarkan permintaan mitra pengabdian). Sejak berdiri di tahun 1995, LB Bagus Palembang sebagai lembaga bahasa terbesar di Palembang telah menerima kelas khusus Bahasa Inggris dibanyak perusahaan besar dan kantor pemerintahan di Palembang dan bahkan beberapa kabupaten di Propinsi Sumatera Selatan. Dari observasi awal dan wawancara sederhana dengan beberapa guru disana, diketahui bahwa mereka membutuhkan pengetahuan pengajaran atau pedagogi untuk kelas dengan murid berkemampuan Bahasa Inggris beragam. Maka dilaksanakanlah pelatihan dengan tujuan memenuhi kebutuhan guru-guru tersebut oleh Tim Pengabdian Kepada Masyarakat Skim Penugasan (PKMSP) Politeknik Negeri Sriwijaya (Polsri) dari Jurusan Bahasa Inggris.

\section{IDENTIFIKASI MASALAH}

Untuk membantu mengatasi masalah kebutuhkan pengetahuan pengajaran atau pedagogi untuk kelas dengan murid berkemampuan Bahasa Inggris beragam, maka Tim Pengabdian Kepada Masyarakat Skim Penugasan (PKMSP) ini mengadakan pelatihan tentang metode pengajaran Bahasa Inggris untuk kelas mixed-English proficiency level bagi guru bahasa inggris di LB-Bagus Palembang. Dalam pelatihan ini, guru-guru di LB Bagus Palembang mempelajari metode pengajaran Bahasa Inggris pada kelas dengan murid yang berkemampuan Bahasa Inggris beragam melalui Differentiated Instructions Methods. Guru-guru ini juga diberi contoh Rencana Pembelajaran (Lesson Plan), Materi Ajar (Teaching Material), dan Alat Uji 
(Assessment Tools). Setelah pelatihan selesai, guru-guru tersebut menggunakan metode yang telah mereka pelajari dalam kelas dengan kemampuan Bahasa Inggris yang beragam yang mereka ajar.

Namun perlu diketahui sejauh mana pandangan atau persepsi mereka dalam menggunakan metode-metode tersebut dalam kegiatan belajar mengajar Bahasa Inggris dikelas mereka. Tujuan dari penelitian ini adalah untuk menyelidiki bagaimana guru Bahasa Inggris LB Bagus Palembang bekerja untuk membantu dan memotivasi siswa dengan berkemampuan beragam mengembangkan potensi mereka dalam kelas Bahasa Inggris. Penelitian ini menjawab pertanyaan penelitian berikut:

(a) Apa pendapat guru tentang siswa berkemampuan beragam di kelas Bahasa Inggris?

(b) Metode dan kegiatan apa yang digunakan guru untuk siswa berkemampuan beragam dalam belajar Bahasa Inggris?

(c) Apa kesulitan dan manfaat dalam memotivasi siswa dalam kelas ini?

\section{METODELOGI PELAKSANAAN}

\section{Teknik Pengumpulan Data}

Metode pengumpulan data yang digunakan dalam penelitian kualitatif ini adalah interview semi-terstruktur. Menurut [7], metode interview digunakan untuk mengetahui cara orang berpikir, merasakan dan bertindak dalam situasi yang berbeda. Interview juga digunakan untuk mengakses opini, perasaan, pengalaman, dan pikiran seseorang [7]. Karenanya, interview semi-terstruktur digunakan dalam penelitian ini untuk mengetahui pendapat, perasaan dan pengalaman guru-guru sebagai responden dari penelitian ini dalam menerapkan metodemetode pengajaran Bahasa Inggris di kelas dengan siswa yang memiliki kemampuan berbahasa Inggris yang beragam. Pertanyaan panduan disiapkan sebelumnya.

Wawancara/interview semi-terstruktur memberikan kebebasan kepada orang yang diwawancarai untuk mengartikulasikan jawabannya [7]. Wawancara dilakukan secara tatap muka, atau one-on-one, hanya antara dua pihak yang terlibat, yaitu yang diwawancarai atau responden dan pewawancara/interviewer. Ini untuk memastikan bahwa para responden merasa senyaman untuk mengemukakan pendapat mereka. Wawancara direkam dengan menggunakan perekam telepon genggam agar pewawancara tidak perlu menulis jawaban sehingga dapat berkonsentrasi penuh pada proses wawancara dan pertanyaannya. Pertanyaan wawancara diadaptasi dari Semistructure Interview Questions for MixedEnglish Class oleh Londres [8].

\section{Teknik Analisa Data}

Data dianalisa dengan cara thematic coding dan categorizing [7]. Ketika semua peserta telah diwawancarai, data yang dikumpulkan kemudian ditranskripsikan. Data yang ditranskripsi dibaca beberapa kali dan dianalisis. Penanda (highlighter) digunakan untuk mengelompokan data berdasarkan tema dan kategorinya. Selanjutnya, data-data tersebut digarisbawahi sesuai dengan tema (thematic coding): 1. pendapat guru, 2 . metode dan kegiatan, dan 3. kesulitan dan manfaat yang dihadapi oleh para guru.

\section{Responden}

Sample responden dalam penelitian ini adalah 6 dari 27 guru-guru LB Bagus Palembang. Keenam responden diindentifikasi dengan nama samara Responden/R 1, R2, R3, R4, R5, and R6. Semua 27 guru tersebut pernah mengikuti pelatihan (pre-service training) metodelogi pengajaran Bahasa Inggris sebelum mereka mulai mengajar di LB Bagus Palembang. Sample dipilih secara acak dari 27 guru tersebut dengan menggunakan metode random sampling atau metode acak. Pemilihan secara acak dilakukan agar semua individu mendapat kemungkinan untuk dipilih menjadi sample dan menghindari bias dari data yang didapat [7, p. 143].

\section{HASIL DAN PEMBAHASAN}

\section{Hasil}

Pendapat Guru tentang Siswa pada MixedEnglish Proficiency Class

Keenam responden sepakat bahwa pengelompokan siswa dengan kemampuan berbahasa Inggris beragam baik bagi siswa itu sendiri. Namun, R1, R4, dan R5 menyarankan bahwa pengelompokan ini tidak selalu berdampak positif bahkan untuk siswa yang paling pintar sekalipun.

Siswa mungkin merasa tidak nyaman untuk berpartisipasi dalam kelompok besar terutama jika siswa lain jelas lebih baik dari mereka. Namun, secara umum, sebagian 
besar siswa mendapat manfaat satu sama lain ketika mereka belajar bersama dalam satu kelas (R1).

$$
\text { Kelas kemampuan beragam sangat }
$$

baik, hanya saya tidak dapat mengelompokan mereka seperti misalnya, siswa dengan kempuan rendah dalam satu kelompok, kemampuan sedang dalam satu kelompok, dan tinggi dalam kelompok lain. Saya bisa melakukannya sementara. Tetapi saya kira, guru juga harus memikirkan siswa berkemampuan tinggi agar mereka tidak ketinggalan hanya untuk membantu yang rendah dan sedang. Namun saya juga sangat prihatin, ketika siswa dengan kemampuan rendah tidak ada yang membantu mereka dalam belajar (R2).

Bahkan jika semua responden berpendapat bahwa sulit bagi siswa berkemampuan cakap untuk belajar dalam kelompok campuran, siswa ini masih lebih suka sistim campuran ini daripada sistim streaming (di mana siswa dikelompokkan sesuai dengan kemampuan mereka). Semua responden sepakat berpendapat bahwa demi kepentingan terbaik siswa, mereka harus belajar bersama. Selain itu, R2 mengklaim bahwa pengelompokan berdasarkan satu kecakapan dapat melukai harga diri mereka yang bukan pelajar cakap. R3 dan R6 juga menyarankan pembelajaran Bahasa Inggris harus dilakukan dalam konteks sosial.

Jika ada dua siswa di kelas yang benar-benar pandai berbahasa Inggris dan mereka dikelompokan untuk belajar dalam satu ruang kelas, maka siswa ini akan kehilangan sosialisasi karena hanya belajar berdua (R3).

Selain itu, siswa berkemampuan cakap akan merasa bosan duduk di ruangan terpisah, melakukan tugas-tugas tambahan sementara siswa lainnya sedang mendiskusikan atau melakukan pelajaran yang sama. R6 mengatakan bahwa ketika siswa berkemampuan cakap dikelompokkan bersama, mereka merasa kaku untuk belajar di kelas.

Saya perhatikan bahwa kelompok teratas memiliki suasana yang cukup tegang bila dikelompokan dlam satu kelas. Mereka butuh beberapa bulan sebelum mereka merasa nyaman satu sama lain (R6).

Menurut guru-guru ini, strategi pengelompokan satu kecakapan ini terkadang berjalan baik bila siswa sendiri memintanya dan juga jika guru menganggap perlu untuk memisahkan siswa karena alasan tertentu.
Namun, pengelompokan siswa sesuai dengan kemampuan mereka untuk jangka waktu yang lama tidak disarankan, pengecualian untuk peraturan seperti misalnya kasus beberapa anak asing yang perlu diisolasi untuk jangka waktu tertentu karen keterbatasan bahasa lokal.

Metode dan Kegiatan untuk Siswa Berkemampuan Beragam

R2, R3, R4, dan R5 dalam mengajar kelas mixed-English profeciency memberi siswa kemampuan cakap materi tingkat advances/lanjut yang sesuai dengan level mereka. R2 bahkan meminjam buku tingkat lanjut di perpustakaan setempat untuk siswa pintar di kelasnya. Ini untuk memastikan bahwa siswa pintar juga dapat belajar dengan baik di kelas kemampuan yang beragam.

R4 menyebutkan bahwa buku teks yang mereka gunakan memiliki banyak latihan dan ini sangat bagus untuk pelajar cepat. Ketika mereka menyelesaikan satu aktivitas, mereka bisa melakukan tugas yang berikutnya. Para siswa berkemampuan tinggi ini tidak harus menunggu teman lainnya menyelesaikan tugas ketika mereka berada di kelas campuran, karena ada banyak kegiatan yang akan membuat mereka sibuk dan tertantang. Ada banyak latihan dalam buku ini dan siswa dapat melakukan latihan sesuai dengan kecepatan mereka. Mereka dapat beralih ke yang berikutnya ketika mereka selesai. Ini bagus ketika Anda mengajar dalam kelompok kemampuan campuran (R4).

R5 juga menegaskan bahwa sangat penting untuk selalu menyiapkan tugas ekstra untuk siswa pintar dapat yang cepat menyelesaikan tugas mereka.

Masalahnya adalah siswa

berkemampuan cakap selalu menjadi yang tercepat. Saya harus menyiapkan kegiatan tambahan untuk mereka. Ada banyak program tambahan di Internet dengan tingkat kesulitan yang berbeda... (R5).

Beberapa guru "lebih otentik" dalam pendekatan mereka. Misalnya, R1 yang menggunakan Skype atau Line untuk komunikasi yang lebih nyata. Dengan kegiatan semacam ini, R1 berpendapat siswa tertantangan dalam belajar karena semua siswa merasa memiliki tugas yang sesuai. R1 menambahkan bahwa setiap siswa memiliki kesempatan yang sama dalam mengembangkan keterampilan berbahasa 
Inggris mereka. Kegiatan semacam ini "Baik untuk siswa yang ingin lebih banyak belajar karena menyenangkan dan siswa menyukainya (R1).

R3 dan R6 meminta siswa pintar mereka untuk melakukan penelitian sederhana, presentasi permainan, presentasi penemuan, wawancara dan membuat video pendek yang dapat dilakukan di luar kelas. R3 menyatakan bahwa guru harus menggunakan berbagai kreativitas siswa untuk belajar Bahasa Inggris.

Mereka mewawancarai beberapa orang, dan membuat video pendek yang sangat menarik. Jadi, siswa dapat lebih kreatif karena mereka sebetulnya memang kreatif. Sangat baik untuk berkerja dalam kelompok dari semua siswa di level yang berbeda dan membiarkan mereka mengembangkan keterampilan mereka lebih lanjut (R3).

R6 menyebutkan bahwa salah seorang siswa berkemampuan tinggi tidak berminat melakukan pekerjaan tertulis karena ia lebih berminat dalam permainan online, ia kemudian ditantang untuk menulis sesuatu tentang permainan online nya dan mempresentasikan permainannya di kelas.

Kesulitan dan Manfaat Memotivasi Siswa dalam Kelas Berkemampuan Beragam

R6 menjelaskan bahwa apa yang dapat dilakukan seorang siswa belum tentu dapat dilakukan oleh siswa lain. Untuk memiliki berbagai kegiatan yang berbeda, seorang guru memerlukan waktu untuk mempersiapkan bahan ajar. Namun, para responden ini mengalami kekurangan atau tidak cukup waktu untuk benar-benar merencanakan dan mendesain kegiatan belajar bagi semua siswa dengan kemampuan berbahasa Inggris yang beragam ke di kelas mereka.

Diperlukan waktu yang lama untuk merencanakan kegiatan belajar tersebut. Jika saya punya cukup waktu, saya bisa menyiapkan tugas yang mungkin lebih baik dan cocok untuk semua siswa (R6).

Mempersiapkan tugas individual persiswa membutuhkan waktu. Menurut semua responden, mereka ingin bersikap adil pada semua siswa. Namun itu berarti para guru ini harus mempertimbangkan semua kebutuhan siswa di kelas mereka, bukan hanya kebutuhan sekelompok siswa dengan kemampuan Bahasa Inggris tertentu.

Keenam responden berpendapat bahwa kelas mereka memiliki rata-rata 25 siswa perkelas, yang berarti terlalu banyak untuk pembelajaran Bahasa Inggris. Namun, satu responden (R2) berpendapat tidak perlu mengurangi jumlah siswa untuk menjadikan kelas lebih kecil, sebaliknya, jumlah guru dapat ditambah untuk menangani kelas tersebut. Menurut R2, sistem pengajaran dengan dua guru dapat bekerja lebih baik. Jika kita dapat memiliki lebih dari satu guru, dua guru di setiap kelas, kita dapat melakukan pengajaran kolaboratif. Seperti, satu guru berkeliling dan memberi bantuan pada siswa yang, berbicara dan mendengarkan mereka, ...satu per satu, satu per satu, dan memotivasi mereka. Jadi dengan lebih banyak guru di kelas atau lebih banyak guru yang tmengajar akan lebih efektif (R2).

R1 dan R5 berpendapat bahwa dua puluh lima siswa dan dua guru dalam satu kelas akan sangat sempurna untuk kelas bahasa, karena guru dapat membagi perhatian pada semua tingkat kemampuan siswa dikelas.

R2, R3, R4, dan R6 setuju bahwa kadangkadang sulit memotivasi siswa yang berkemampuan tinggi untuk belajar hal-hal baru. Mereka beranggapan sudah tahu segalanya. Para responden ini mengatakan sangat memprihatinkan ketika siswa menolak mengerjakan tugas yang berbeda. R3 menawarkan siswa berkemampuan tinggi dikelasnya untuk membaca buku-buku tingkat lanjut dan menceritakan hasil bacaannya di kelas tetapi siswa ini menolak.

Saya sebenarnya telah mengusulkan proyek penelitian untuk dua siswa dengan kemampuan yang lebih tinggi, tetapi mereka tidak bersedia. Saya tidak tahu apakah ini adalah zaman modern atau hanya kemalasan atau mereka enggan untuk berkerjasama dengan siswa yang lebih rendah kemampuannya (R3).

Semua responden sepakat bahwa kesediaan guru untuk membantu siswa berkemampuan cakap akan lebih berhasil jika siswa itu sendiri tahu cara dn mau bekerja sama. Seperti yang dialami oleh para guru ini, kurangnya kemauan siswa untuk bekerja sama mengacaukan tugas tambahan yang telah mereka buat.

\section{Diskusi}

\section{Manfaat Kelas Kemampuan Beragam}

Semua responden dalam penelitian ini menguatkan pendapat Bailey dan Bridges [9, 
p. 19] bahwa integrasi siswa dengan kemampuan beragam dalam satu kelas akan mempererat integrasi sosial dan membantu mengurangi keengganan siswa yang kurang mampu untuk belajar. Semua responden juga setuju bahwa kelas dengan siswa beragam kemampuan dapat belajar satu sama lain didalam kelas tersebut. Siswa yang berkemampuan tinggi dapat dijadikan contoh dan siswa lain saling belajar. Mereka menjadi lebih toleran dan menunjukkan rasa saling menghormati dan pengertian dalam proses belajar mereka.

Selain itu, responden juga berpendapat bahwa mereka lebih suka kelas dengan beragam kemampuan daripada kelas dengan satu tingkat kemampuan seperti yang juga dinyatakan oleh Xanthou dan Pavlou [10]. Xanthou dan Pavlou berpendapat bahwa siswa yang kurang mampu memiliki peluang untuk dibantu oleh siswa yang lebih mampu. Namun, reaponden juga mengklaim bahwa pengelompokan kemampuan beragam juga memiliki sejumlah kelemahan seperti guru harus mengajar dengan tingkat rata-rata, tidak terlalu cepat dan tidak terlalu lambat. Ini berarti bahwa siswa yang mampu tidak tertantang oleh sistim belajar semacam ini dan bagi siswa yang kurang mampu tidak selalu dapat mengikuti tugas diskusi karena lebih didominasi oleh siswa yang berkemampuan tinggi. Ini merupakan situasi yang kompleks tetapi para responden bereksperimen dengan beberapa cara untuk membantu siswa berkemampuan tinggi mengembangkan kemampuan mereka ketika belajar dengan siswa dengan kemampuan lebih rendah dari mereka.

\section{Instruksi yang Berbeda}

Seperti yang telah dibahas diatas, para responden mencoba untuk menjadikan instruksi pembelajaran mereka lebih personal. Dengan cara menyiapkan berbagai bahan pengajaran yang sesuai dengan masing kebutuhan siswa dalam kelas, diharapkan semua siswa mampu belajar bersama. Para responden menyebut instruksi mereka dengan istilah instruksi bervariasi atau pelajaran khusus. Jelas bahwa guru-guru ini mencoba menantang proses berpikir siswa mereka dengan cara memberikan kegiatan yang menarik dan meningkatkan kemampuan berbahasa Inggris mereka. Sikap responden terhadap siswa mereka ini memverifikasi asumsi Blaz (2015, p. 3) dalam bukunya, Differentiated Instruction - A Guide for World Language Teachers bahwa instruksi yang berbeda dapat berfungsi dengan baik bila guru dapat mengidentifikasi perbedaan di antara siswanya. Kemudian, guru menyesuaikan dengan kemampuan siswa dan memfasilitasi pembelajaran mereka di kelas. Responden telah mengidentifikasi kemampuan siswa mereka dan dari awal menyiapkan pelajaran, kegiatan, dan proyek yang akan membawa siswa ke proses pembelajaran yang lebih maju. Misalnya, memberikan buku tugas tambahan, bahan bacaan, menugaskan proyek video pendek, penelitian sederhana, dan presentasi penemuan. Responden juga telah memberikan siswa berkemampuan tinggi tugas dalam kegiatan percakapan online. Contoh-contoh ini digunakan para responden untuk memotivasi siswa dalam kelas Bahasa Inggris yang berkemampuan beragam.

\section{Zona Pengembangan Proksimal}

Penelitian ini juga mengkonfirmasi teori Van de Veer [12] bahwa siswa yang berkemampuan tinggi harus mendapat tantangan lebih besar untuk menghindari rasa bosan dan kehilangan tujuan mereka dalam belajar di kelas. Van der Veer berargumen bahwa siswa ber-IQ tinggi tidak terlalu mendapatkan manfaat dalam proses belajar di kelas karena lebih banyak siswa berkemampuan sedang atau rendah yang harus diperhatikan oleh guru. Berbeda dengan argumen ini, tampaknya siswa dari responden penelitian ini dapat belajar dengan baik di kelas mereka karena mendapat kegiatan yang berbeda namun sesuai dengan masing-masing kemampuan mereka. Akan tetapi, seperti yang disebutkan sebelumnya, ada beberapa siswa berkemampuan tinggi yang menolak tugas tambahan dari guru mereka tapi ada juga yang bersedia mengerjakan tugas tersebut.

\section{KESIMPULAN}

Tujuan dari penelitian ini adalah untuk mengetahui bagaimana guru Bahasa Inggris LB Bagus Palembang berupaya untuk membantu dan memotivasi siswa dengan kemampuan beragam mengembangkan potensi mereka di kelas Bahasa Inggris. Tujuan ini mungkin tidak sepenuhnya terwujud karena beberapa kekurangan dalam teknik dan analisis interview yang diberikan. Namun, sejumlah temuan menarik muncul untuk 
praktik pengajaran Bahasa Inggris di kelas dengan kemampuan beragam.

Pertama, tentang pendapat guru yang memiliki siswa berkemampuan beragam di kelas mereka. Kelas dengan siswa berkemampuan beragam adalah aset bagi guru untuk mengembangkan kemampuan mengajar mereka. Selain itu, mereka mengakui bahwa memotivasi semua siswa dalam kelas dengan kemampuan yang beragam merupakan hal yang sangat menantang. Para guru harus memenuhi kebutuhan siswa yang berbeda, mengajarkan siswanya bersosialisasi, menggunakan kreativitas mereka, dan belajar untuk bersikap toleran dan lebih memahami teman sekelas mereka.

Kedua, para guru ini menggunakan berbagai metode dan kegiatan untuk mengajak siswa dengan berkemampuan beragam belajar Bahasa Inggris. Berdasarkan data yang didapat, semua responden menggunakan instruksi yang berbeda untuk mengakomodir semua kebutuhan yang berbeda dari semua siswa di kelas mereka.

Ketiga, para guru ini juga menemukan kesulitan dan juga manfaat dalam memotivasi siswa di kelas dengan kemampuan beragam. Kesulitan yang ditemukan adalah banyak siswa berkemampuan tinggi tidak ingin dibedakan materi ajarnya. Hal ini merupakan kendala bagi guru untuk memotivasi siswa mengembangkan potensi belajar mereka. Motivasi sangatlah penting, karena tanpa motivasi yang tepat, para siswa tidak akan melihat pentingnya berjuang untuk memiliki kemampuan berbahasa Inggris yang baik.

\section{UCAPAN TERIMA KASIH}

Penelitian ini merupakan tindak lanjut dari Pengabdian Kepada Masyarakat Skim Penugasan (PKMSP) Politeknik Negeri Sriwijaya (Polsri) dalam melaksanakan Pelatihan Metode Pengajaran Bahasa Inggris untuk Kelas dengan Siswa Mixed-English Proficiency Level bagi Guru-guru Bahasa Inggris di Lembaga Bahasa (LB)-Bagus Palembang (nama disamarkan berdasarkan permintaan mitra). Program PKMSP ini dibiayai oleh PNBP Polsri dan Mitra (LB Bagus Palembang). Namun dana dari mitra tidak didapat dalam bentuk tunai dan tidak diberikan kepada Tim PKMSP, melainkan dalam bentuk penyedian gedung pelatihan, biaya perjalanan dan makan, dan penggandaan bahan ajar dan materi ajar bagi guru-guru LB
Bagus Palembang sendiri. Penulis mengucapkan terima kasih kepada semua pihak yang telah memberi dukungan finansial terhadap terhadap pelaksanaan pengabdian ini.

\section{REFERENSI}

[1] S. Handayani, "Pentingnya kemampuan berbahasa inggris sebagai modal dalam menyongsong ASEAN COMMUNITY 2015," pp. 102-106, 2016.

[2] J. Ujihanti, M., Ardiansyah, W., Suroso, Jabar, M. B, Amalia, R., Pelatihan Penerapan Metode Pengajaran Totall Physical Response (TPR) bagi Guru Bahasa Inggris Madrasah Ibtidaiyah di Pondok Pesantren Al-Amalul Khair Palembang: Unpublished Report of Teacher-Student Collaboration in Community Service Program Palembang. 2017.

[3] D. Crystal, "English Worldwide," in $A$ History of the English language., R. M. Denison, David; Hogg, Ed. 2016, pp. 420-439.

[4] D. Lyons, "How many people speak English, and where is it spoken?," Babble Magazine, 2017.

[5] S. F. Rashor, "Bahasa Asing Penunjang Keberhasilan AEC 2015," 2013.

[6] Y. Sulistyoningrum, Kursus Bahasa Inggris Saat Ini. 2015.

[7] J. W. Creswell, Educational research: Planning, conducting, and evaluating quantitative and qualitative research, 4th ed. Boston, 2012.

[8] A. Londres, "Keeping Up With the High-Ability Students: Teacher's Perspectives on Helping High-Ability Students in Mixed-Ability English Classes," Linnaeus University, 2017.

[9] D. Bailey, C. \& Bridges, Mixed Ability Grouping - A Philosophical Perspective. New york, 1983.

[10] M. \& P. Xanthou, "Strategies of accommodating mixed ability classes in EFL settings," Humaniz. Lang. Teaching, (10) 1, 2008.

[11] D. Blaz, Differentiated Instructions: A Guide for World Language Teachers, 2nd Editio. New York, 2015.

[12] R. Van Der Veer, Lev Vygotsky. London, 2007. 